\title{
Respiratory Electron Transport System Activity as a Measure of the Effect of Toxicants on a Natural Freshwater Phytoplankton Community
}

\author{
Hakumat Rai ${ }^{1}$, Mitsuru Sakamoto ${ }^{2}$, Yatsuka Saijo ${ }^{2}$, \\ and KAZUSHI TAKAHASHI ${ }^{2}$ \\ 1. Max-Planck-Institut für Limnologie, Abteilung Ökophysiologie, Plön, West Germany. \\ 2. Water Research Institute, Nagoya university, Nagoya, Japan.
}

\begin{abstract}
This paper describes the value of adopting differential fractionation technique for ETS activity measurements when studying the biological interactions in natural planktonic assemblages. The application of ETS activity measurements in assessing in a relatively short time the effects of toxicants on phytoplankton communities is discussed.
\end{abstract}

Key words : ETS-activity, biological interactions, differential fractionation, phytoplankton

\section{Introduction}

Various methods have been described for measuring quantitatively the effect of toxicants on algae. These methods generally entail the measurment of growth rates, photosynthetic activity, or nutrient uptake rates. Direct cell counts by microscopy method for growth rates do not distinguish living from dead cells. Because respiration is closely associated with active cellular metabolism, the detection of dehydrogenase activity has been used to detect living bacterial cells (Zimmermann et al., 1978). Such enzyme activity has been described as electron transport system (ETS) activity, which is a prevalent component of respiring organisms (Packard, 1971). Lowered ETS activity is associated physiologically with cell senescence cells. Respiratory activity drops in senescing cells since energy is no longer required for the synthesis of nucleic acid, proteins and other compounds associated with normal cell division, growth and maintenance. It is expected, however, that in vitro ETS activity will remain relatively constant, as there should be essentially no turnover of respiratory proteins until after the cells are dead (Packard, 1985) and normal biological integrity is lost. Until death the respiratory machinery is intact and functional, although metabolic activity is maintained at a low level.

Application of the respiratory electron transport system (ETS) approach is particularly attractive in view of the fact that the basic ETS occurs universally in organisms from bacteria to man, and ETS activity is the basis of aerobic and anaerobic respiration (Jones, 1977 and Payne, 1976). Moreover, the rate of such enzymatically controlled processes can be measured rapidly and measured with considerable accuracy and sensitivity (Kenner \& Ahmed, 1975).

Rapid methods are needed to assess the effects of toxicants on planktonic organisms. Since ETS activity measurement has such outstanding merit for detecting the physiological state of a biotic community, a very sensitive spectrophotometric method (Rai, 1984) for measuring the ETS activity of a the natural plankton population was applied to experimentally enclosed communities during exposure to a pesticide-Temephos (phosphororth- 
ioic acid (o, o'-(thiodi-4,1-phenylene) to (o,o, $\mathrm{o}^{\prime}$, $\mathrm{o}^{\prime}$-tetramethyl ester)). Further, because respiration is associated closely with active cellular metabolism, the detection of ETS activity was expected to differentiate living from dead plankton communities.

This paper describes the adaptation of ETSactivity measurement for studying microbial interactions in natural plankton assemblages in a lake ecosystem. It also discusses the application of ETS activity measurements in assessing the effects of toxicants on phytoplankton communities, in a relatively short time.

This experimental work is a part of extensive studies on the biological interactions occuring in natural plankton assemblages in experimental enclosures at Lake Suwa, Japan. Further results on experiments conducted in Lake Suwa experimental enclosures on biological interactions will be reported by the members of our research group.

\section{Materials and Methods}

The experiment was carried out during August and September 1986, using the experimental enclosure facilities in the hypertrophic Lake Suwa, Central Japan. Four large open-bottom enclosures $(5 \times 5 \times 4.2 \mathrm{~m})$ were filled simultaneously with natural lake water. Large plankton were removed partially by repeatedly filtering the water with a $40-\mu \mathrm{m}$ net from enclosure number $4 \& 5$. During the experiment no nutrients were added to the contents of any enclosure.

Details of the treatment design are summarized below :

\section{TYPE OF TREATMENT}

No treatment (control)

Temephos added $\left(0.5 \mathrm{mg} \cdot \mathrm{1}^{-1}\right)$

ENCLOSURE NUMBER

Partial removal of plankton greater than $40-\mu \mathrm{m}$ (control)

Partial removal of plankton greater than $40-\mu \mathrm{m}$ and Temephos added $\left(0.5 \mathrm{mg} . \mathrm{l}^{-1}\right)$
\{The pesticide Temephos employed in the present study was an emulsified solution [Temephos (5\%) with emulsifier $(5 \%)$ in xylene], supplied by Sankyo Co., Ltd., Japan.\}

The natural plankton populations in enclosures 2 and 5 were exposed to Temephos $\left(0.5 \mathrm{mg} \mathrm{1}^{-1}\right)$ on Aug. 11, 1986 just after initial samples were taken from all the enclosures and open lake water. Water samples from the experimental enclosures were collected with a Plexi-glass tube sampler that could be opened at any desired depth. This sampler was specially designed to collect a 2-m water column at one time. All enclosures were sampled at about 0900 hours. To study the various parameters with depth, integrated samples were collected at depths of 0-2 and 2-4 m.

\section{Fractionation and Sample Preparation for ETS Assay}

Fractionation was carried out by filtering the integrated samples through $40-\mu \mathrm{m}$ and $10-\mu \mathrm{m}$ nylon screens, respectively, without applying any suction pressure. For the ETS-activity determination, duplicate aliquot subsamples of each fraction as well as an unfractionated sample were then filtered through a $25-\mathrm{mm}$ diameter glass microfiber filter, (Whatman $\mathrm{GF} / \mathrm{F}$, precombusted at $450^{\circ} \mathrm{C}$ ) under low vacuum (ca. $50 \mathrm{mmHg}$ ). Utmost care was taken not to suck the filters dry during the filtration process.

\section{ETS-Activity Assay}

Each filter was placed in a glass reaction tube with 3-ml of homogenization buffer and sonicated for 3 min. using an ultrasonic disrupter (Model UR-200 P, Solid State, Tomy Seiko Co., Ltd., Tokyo, Japan). Sonication was carried out at ca. $0-4^{\circ} \mathrm{C}$. A $1-\mathrm{ml}$ portion of the homogenate was incubated for $10 \mathrm{~min}$. at an in situ enclosure temperature with $3-\mathrm{ml}$ of substrate and $1-\mathrm{ml}$ of INT solution [2-p-idophenyl-3-p-nitrophenyl-5phenyltetrazolium chloride] in a waterbath. The 
reaction was stopped by adding $1-\mathrm{ml}$ of reaction termination mixture. The reaction tubes were incubated further for $5 \mathrm{~min}$. The controls were run in the same manner using $1-\mathrm{ml}$ of homogenization buffer, but the reaction was stopped before incubation by adding 1-ml of reaction termination mixture.

The formazan (reduced INT) solution in the reaction tube was clarified by centrifugation at ca. $5,000 \mathrm{rpm}$ and optical density was measured at 490 $\mathrm{nm}$ spectrophotometrically in a $1-\mathrm{cm}$ path length cuvette, using a UV-visible light spectrophotometer (Model UVIDEC-610, Spectronic Co., Ltd., Tokyo, Japan). ETS activity was measured as the rate of INT reduction, which was then converted to equivalent oxygen. In converting respiration to carbon units, an RQ of 1.0 was then taken into consideration.

The ETS activity was calculated according to the following equation :

$$
\text { ETS-activity }=\frac{\mathrm{E}_{\text {cor }} \cdot \mathrm{V}_{\text {hom }} \cdot 60 \cdot \mathrm{V} \cdot 100 \cdot 1.42 *}{1.42 \cdot \mathrm{V}_{\mathrm{sam}} \cdot 100}
$$

where

$$
\begin{aligned}
& \text { ETS-activity }=\mu \mathrm{g} \mathrm{O}_{2} \cdot \mathrm{h}^{-1} \cdot \mathrm{1}^{-1} \text {. } \\
& \mathrm{E}_{\mathrm{cor}} \quad=\text { corrected extinction against blank } \\
& \text { sample } \\
& \mathrm{V}_{\text {hom }} \quad=\text { volume of homogenate in } \mathrm{ml} \text {. } \\
& 60=\text { factor for conversion to hours } \\
& 1000=\text { factor for conversion to liters. } \\
& 1.42^{*}=\text { factor for conversion to volume } \\
& \mathrm{O}_{2} \text { to mass } \mathrm{O}_{2} \text {. } \\
& 1.42=\mu \mathrm{mol} \text { volume } \mathrm{O}_{2} / \text { extinction of } 2 \\
& \mathrm{~V}_{\text {sam }} \quad=\text { volume of water sample filtered in } \\
& \text { ml. } \\
& 10=\text { reaction time in minutes (incuba- } \\
& \text { tion period). } \\
& \mathrm{V}=\text { final reaction volume in } \mathrm{ml} \text {. }
\end{aligned}
$$

Details of the sample treatment, fractionation and further handling of the samples for ETS assay used in this study are discussed in Rai (1984).
Chlorophyll was determined according to the method described by Marker et al. (1980).

\section{Results and Discussion}

Most previous toxicological investigations have been performed in the laboratory, and have been of short duration and limited to single species. Therefore it is difficult to comment on the significance of the results obtained in terms of natural aquatic environments. Long term experiments with more complex systems using large plastic bags containing planktonic communities and suspended in natural water have been reported to bridge the gap between laboratory and natural conditions (Strickland \& Terbune, 1961; Goldman, 1962; Schelske \& Stoermer, 1971, 1972; Horstmann, 1972 ; Brockman et al., 1974; Parson, 1974 ; Kuiper, 1977).

Lake Suwa water, with which the present enclosures were filled, contained heavy algal bloom of Microcystis spp. during the period of study. Figures 1 and 2 show the ETS activity $\left(\mu \mathrm{g} \mathrm{C} \cdot 1^{-1}\right.$ $\cdot \mathrm{h}^{-1}$ ) and percentage composition of respiratory enzyme activity in different size fractions for Lake Suwa and experimental enclosures during the period of study (11 August to 27 September 1986).

The patterns of ETS activity found in control enclosure 4 are similar to those of open water (Figs. 1 and 2). However it is surprising to note that enclosure 1, which received no treatment, did not mimic the ETS activity patterns found in the open water (Figs. 1 and 2). In enclosures 2 and 5, before the application (11 August 1986) of Temephos, planktonic particles greater than $10-\mu \mathrm{m}$ in size contributed $60 \sim 80 \%$ of the ETS activity (especially in $0-2 \mathrm{~m}$ integrated samples, the effect of Temephos was very apparent). The addition of Temephos induced a remarkable decrease in the ETS activity of larger particles, but the contribution of the smaller planktonic particles (less than $10-\mu \mathrm{m}$ ) became more apparent after the application of the toxicant.

From the data, it appears that the greater than 40 

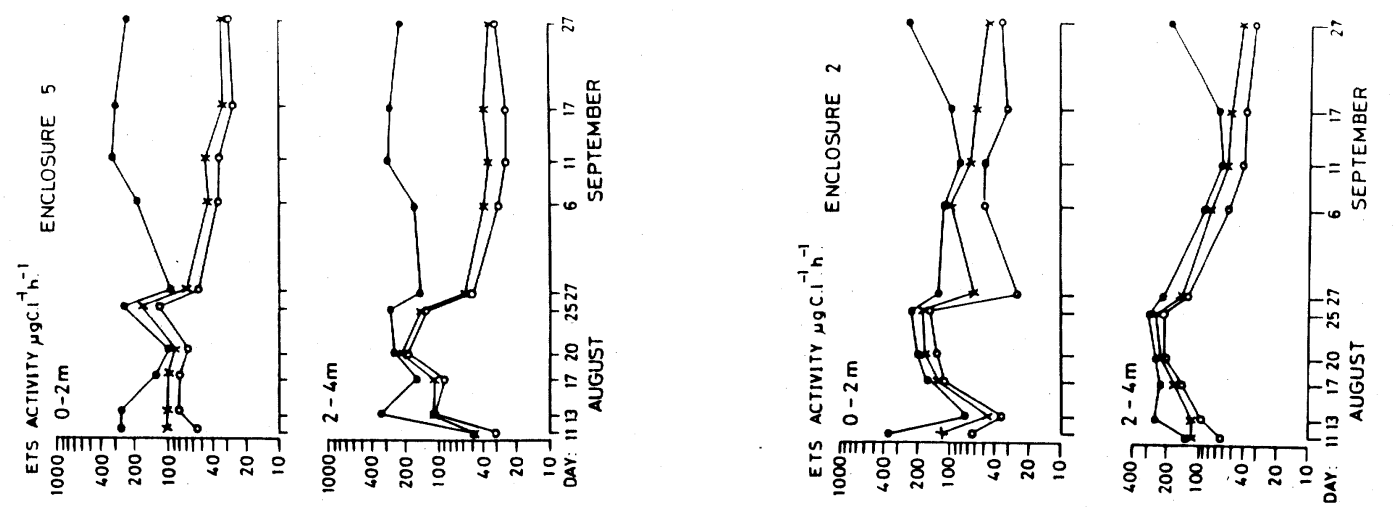

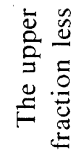

总

究

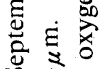

के

도

悹视总

< 50

E

3.
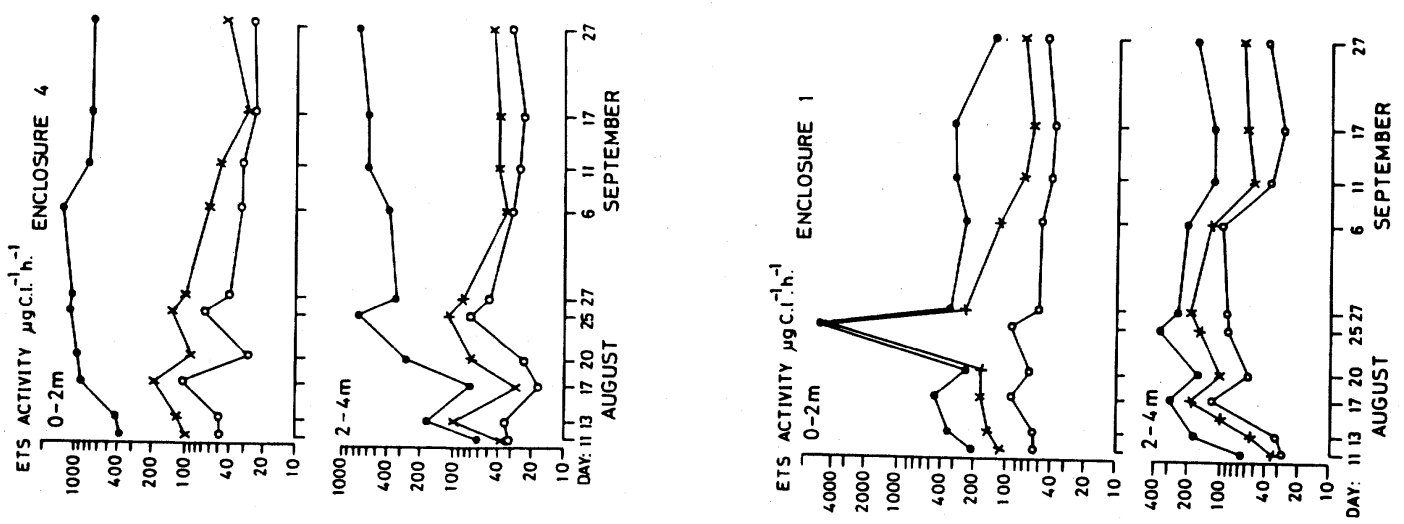

홍용요

造

要

急

(5)

훈

政

क्ष

둥

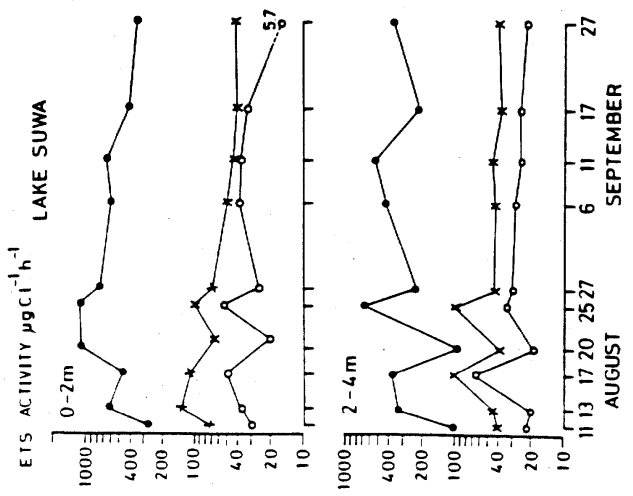

这

를

홍

氜

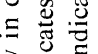

2. ․․․

ज्ञ

s.

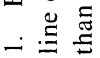

id 

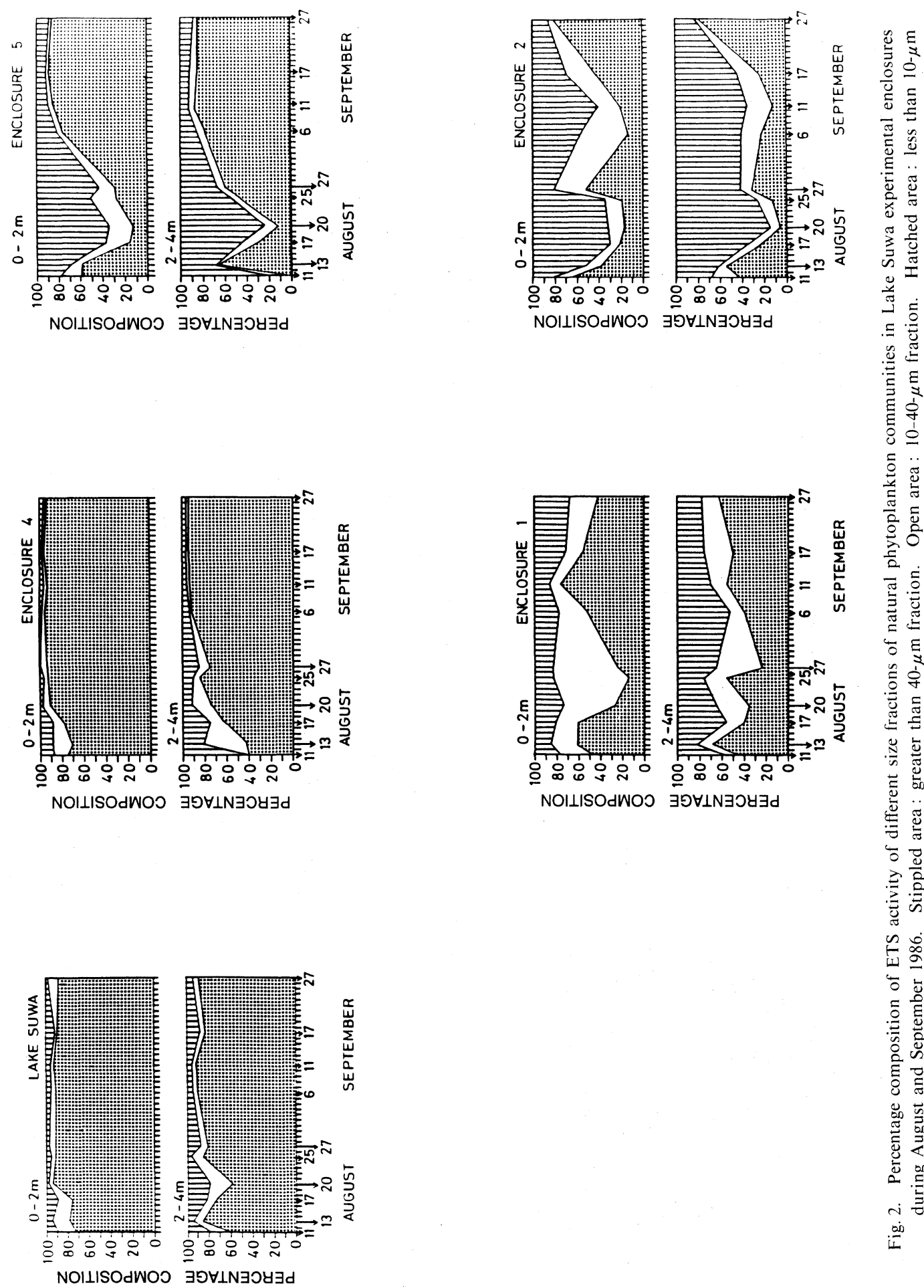

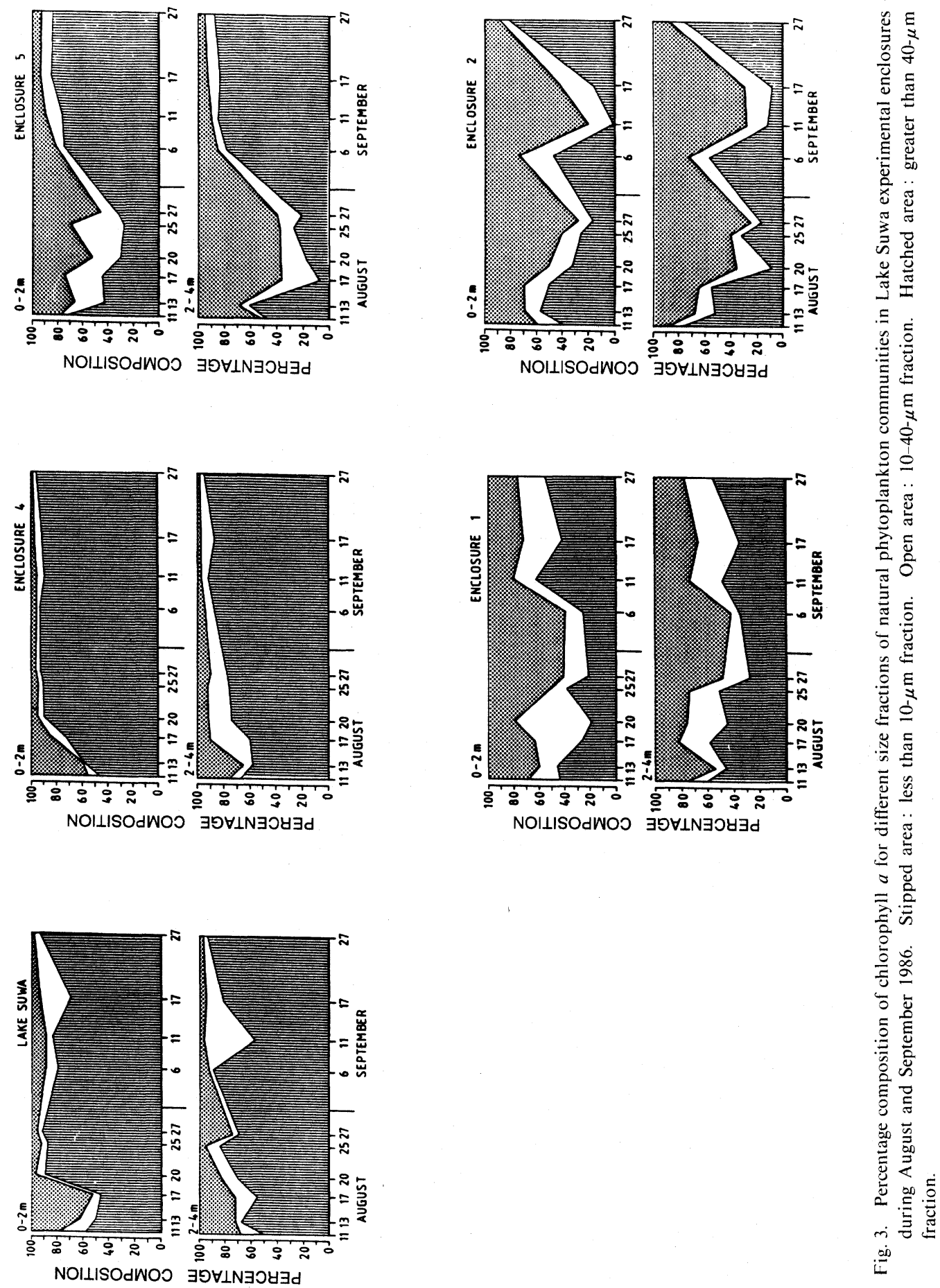
$\mu \mathrm{m}$ size fraction of planktonic organisms (including zooplankton) were killed rapidly by the toxic effect of Temephos. This effect was clearly seen during the filtration process, as no cladocerans or copepods were retained on the $40-\mu \mathrm{m}$ net. The elimination of zooplankton, especially the herbivorous cladocerans and copepods, thus changed the biological interactions as well as the physicochemical conditions in the planktonic community within the of the enclosures containing Temephos (Figs. 1 and 2). Losses among the larger planktonic particles (greater than $40-\mu \mathrm{m}$ ) were also indicated by the decreased ETS activity of this fraction. It is clear from Fig. 2 that about 9 days after Temephos was applied the relative percentage contribution to ETS activity of this fraction (greater than $40 \mu \mathrm{m}$ ) decreased from the initial value ca. $80 \%$ to $20 \%$ of total community activity. This effect was especially clear in 0-2 m integrated samples as compared with 2-4 m integrated samples. ETS activity was approximately $20 \%$ of that in the control enclosures (Fig. 1).

The effect of Temephos was accompanied by very significant shifts in the distribution of ETS activity in different size fractions (Figs. 1 and 2). As mentioned above, physiologically lowered ETS activity is expected in senescing cells. This expectation was born out in the observed remarkable decreases in ETS activity values of particles greater than $40-\mu \mathrm{m}$ as time of exposure to the toxicant increased (Figs. 1 and 2).

As explained above, after the larger particles had been killed by the lethal action of the Temephos, they transported Temephos to the bottom through processes such as flocculation and sedimentation. The Temephos must have been sedimented by such sinking of dead particles, because only a little Temephos was detected in the filtered water samples even a week after the addition of the Temephos (personal communication from Dr. T. Iwakuma, National Institute of Environmental Studies, Tsukuba, Japan). It is also possible that the Temephos was decomposed by microorganisms in the water column. It appears therefore that the smaller particles (less thas $10-\mu \mathrm{m}$ fraction) were not exposed sufficiently to Temephos and thus escaped lethal doses of the toxicant (Figs. 1 and 2). A mssive development of larger plankton (greater than $40-\mu \mathrm{m}$ ) occurred about three weeks after exposure to Temephos. This might have happened due to the disappearance of Temephos from the water column, and therefore, smaller colonies of Microcystis spp. grew at their normal rate and soon dominated the plankton communities in the treated enclosures 2 and 5 (Figs. 1 and 2).

Figure 3 shows, as a function of time, the chlorophyll $a$ percentage contribution by different size fractions of phytoplankton from the experimental enclosures and open water. The patterns of chlorophyll $a$ found in the control enclosure 4 were similar to those of the open water (Fig. 3). As in the case of ETS activity (Figs. 1 and 2) it is again surprising to note that enclosure 1 , which received no treatment, did not mimic the open lake water. Further, it is also interesting that the patterns of ETS activity (Fig. 2) were similar to the patterns of the chlorophyll $a$ for the enclosures studied, because ETS activity is at best an estimate of the potential for respiration and is closely related to living phytoplankton biomass (chlorophyll $a$ ).

This means that our parameter (ETS activity) used for measuring the effects of toxicants on natural populations of phytoplankton communities could be adapted for studying microbial interactions and their dynamics in natural plankton assemblages in a lake ecosystem.

In conclusion it may be mentioned that our study clearly demonstrated that smaller planktonic particles (less than $10 \mu \mathrm{m}$ ) were not affected by Temephos, but instead became stimulated in the absence of greater than $40-\mu \mathrm{m}$ particles (Fig. 1), which were killed by the toxicant. This study also strongly supports the conclusion that ETS activity measurement is a useful tool and a rapid method for assessing the effects of toxicants on phytoplankton communities over relatively short time period. Further, this type of study might 
allow rapid assessment of the effects and the pathways of various toxic pollutants, heavy metals and contaminants through size fractions of phytoplanktonic organisms, and subsequently through the food chain.

\section{Acknowledgements}

We thank the Japan Society for the Promotion of Sciences (JSPS) for granting a fellowship to Hakumat Rai to conduct joint research work with the Water Research Institute, Nagoya University, Nagoya, Japan, and Max-Planck-Institut für Limnologie, Abteilung Ökophysiologie, Plön, West Germany. This study was also supported by a Grant-in-Aid for Special Research Project No. 61134044 from The Ministry of Education, Science and Culture, Japan.

\section{References}

Brokman, U.H., K. Eberlein, H.D. Junge, M. Trageser, und K.J. Trahms, 1974. Einfache Folientanks zur Planktonuntersuchung in situ. Mar. Biol., 24, 163-166.

Goldmann, C.R., 1962. A method of studying nutrient limiting factors in situ in water columns isolated by polyethylene film. Limnol. Oceanogr., 7, 99-101.

Horstmann, U., 1972. Uber den Einfluss von hauslichem Abwasser auf das Plankton in der Kieler Bucht. Kieler Meeresforch. 28, 178-198.

Kenner, R.A., and S.I. Ahmed, 1975. Correlation between oxygen utilization and electron transport activity in marine phytoplankton. Mar. Biol., 33, 129-133.

Kuipemr, J., 1977. Development of North Sea coastal plankton communities in separate plastic bags under identical conditions. Mar. Biol., 44, 97107.
Jones, C., 1977. Aerobic respiratory system in bacteria. In: Microbial metabolic regulations by adenine nucleotide pools. Vol.27. Microbial energetics. (edited by B.A. Haddok W.A. Hami (ton). pp. 23-59. Cambridge, London.

Marker, A.F.H., E.A. Nusch, H. Rai, and B. Riemann, 1980. The measurement of photosynthetic pigments in freshwaters and standardization of methods: Conclusions and recomendations. Arch. Hydrobiol. Beih./Ergebn. Limnol., 14, 91-106.

Packard, T.T., 1971. The measurement of respiratory electron transport activity in marine phytoplankton. J. Mar. Res., 29, 235-244.

Packard, T.T., 1985. Oxygen consumption in the Ocean: Measuring and mapping with enzyme analysis. In: Mapping strategies in chemical oceanography symposium based on analysis for mesoscale and macroscale-1983. processes (edited by A. Zirino) American Chemical Society. Advances in Chemistry Series., 209. Wash., D.C

Parsons, T.R., 1974. Constrolled ecosystem pollutioon experiment. (CEPEX). Envir. Conser., 1, 224.

Payne, W., 1976. Denitrification. Trends in Biochemical Sciences., 1, 220-222.

Rai. H., 1984. Size-dependent respiratory-enzyme activity and primary production of microplankton in Schöhsee (a North German Baltic lake). Arch. Hydrobiol., 102, 239-253.

Schelske, C.L., and E.F. Stoermer, 1971. Eutrophication, silica depletion and predicted changes in algal quality in Lake Michigan. Science, N.Y. $173,423-424$

Strickland, J.D.H., and L.D.B. Terhune, 1961. The study of in situ marine photosynthesis using large plastic bag. Limnol. Oceanogr., 6, 93-96.

Zimmermann, R., R. Iturriaga, and J. Becker-Birk, 1978. Simultaneous determination of the total number of aquatic bacteria and the number thereof involved in respiration. Appl. Environ. Microbiol, 36, 926-935.

(Received July 13, 1988-Accepted February 10, 1989) 